\title{
Implications of Development Bank Finance on the Growth and Development of Msmes in Nigeria (2010-2017)
}

\author{
Adewole Joseph Adeyinka
}

M.Sc., Department of Banking and Finance, Faculty of Management and Social Sciences, Adekunle Ajasin University, P.M.B 001, Akungba Akoko, Ondo State, Nigeria

Muhammed Abdulkarim

Department of Banking and Finance, Faculty of Management Science, Kogi State University, Anyigba Kogi State, Nigeria

\section{Nwankwo Odi}

FCIB, PhD, Department of Banking and Finance, Faculty of Management Science, Kogi State University, Nigeria

\begin{abstract}
Developing a sustainable source of finance for MSMEs has remained a perennial problem as a result of their poor accounting systems and lack of, or low-valued collaterals. This study examined the impact of development bank finance on the growth and development of MSMEs in Nigeria from 2010 - 2017 with specific objectives of determining whether MSMEs have poor accounting systems, the extent to which SMEs financing depend on sound accounting practices and whether MSMEs funding depend on collateral using the survey research design method. Ordinary Least Square Regression (OLS) Technique was used to analyse the data obtained from primary and secondary sources. The study found that MSMEs in Nigeria have a poor accounting practice, access to finances by MSMEs depend largely on a sound accounting practice and that the volume and value of credits to MSMEs depend on the availability of collaterals. The study recommends that SMEs should install a sound internal control system MSMEs should ensure a sound accounting practice that conforms with the internationally accepted accounting standards in order to boost their access to funding, and MSMEs should invest a portion of their capital in non-current assets in order to increase the value of their collaterals and, hence, have expansive access to funding.
\end{abstract}

Keywords: Sound Accounting Practices, Collateral, Non-Current Assets, and funding.

JEL Classification: G2, G21.

Cite as: Adeyinka, Ad. J., Abdulkarim, M., Odi, N. (2019). Implications of Development Bank Finance on the Growth and Development of Msmes in Nigeria (2010-2017). Financial Markets, Institutions and Risks, 3(3), 28-48. http://doi.org/10.21272/fmir.3(3). 28-48.2019.

(C) The Authors, 2019. This article is published with open access at Sumy State University.

\subsection{Background to the Study}

The development of Micro, Small and Medium Enterprises are fundamental to the growth and development of any economy. They provide easy employment opportunities and are keys to poverty alleviation. Small and medium enterprises (SMEs) play a major role in economic development in every country, including in African countries. Studies indicate that in both advanced economies and developing countries SMEs contribute on average, 60 percent of total formal employment in the manufacturing sector (Ayyagari, 2007). For African economies, the contribution of the SME sector to job opportunities is even more important. Taking into account the contribution of the informal sector, SMEs account for about three-quarters of total employment in manufacturing (Ayyagari, 2007). According to Singh and Wasdani (2010), Micro, Small, and Medium-sized Enterprises (MSMEs) have gained increased attention in India in recent times, considering their strategic importance to the economy and the country. MSMEs play an important role in generating employment - 48.8 million MSMEs in the country provide employment to 111.4 million people. 
MSMEs in the manufacturing sector alone produce more than 6,000 products and contribute $7.7 \%$ of the GDP of the country. Similarly, MSMEs in the services sector contribute $27.4 \%$ of the country's GDP. With relatively low start ups, MSMEs engage at least five persons and reduce the pressure in the labour market. Because of the strategic position they occupy in the economy, and the increasing needs to reduce poverty, unemployment, and improve the standard of living, the modalities, sources, and effective strategies for financing small and medium enterprises have been a major source of concern to various governments in the developing countries. Singh and Wasdani (2010) maintained that finance for micro, small, and mediumsized enterprises (MSMEs) has been a concern for all stakeholders including entrepreneurs, financial institutions, and government organizations.

The Nigerian government through the Central Bank of Nigeria in a bid to curb unemployment reduce poverty and increase the standard of living and in recognition of the roles of small and medium enterprises in the economic development launched the new modalities for financing small and medium enterprises in 2013. As part of its developmental functions and mandate of promoting a sound financial system in Nigeria, the Central Bank of Nigeria launched the Micro, Small and Medium Enterprises Development Fund (MSMEDF) on August 15, 2013. This was in recognition of the significant contributions of the Micro, Small and Medium Enterprises (MSME) sub-sector to the economy (CBN, 2014). Despite the efforts of the government and other stakeholders, financing micro, small and medium enterprises have remained perennially difficult. This is partly due to the high mortality rates of small and medium enterprises with $80 \%$ failure in the first five years of their operations, and partly due to low or non-existent collateral. Although, the government is consistently taking steps to increase access to funding through policy design and implementation, but the desired results have not been achieved. According to the Central Bank of Nigeria (2014), the sub-sector is characterized by huge financing gap which hinders the development of MSMEs. Section 6.10 of the Revised Microfinance Policy, Regulatory and Supervisory Framework for Nigeria, stipulates that 'a Microfinance Development Fund shall be set up, primarily to provide for the wholesale funding requirements of MFBs/MFIs'. To achieve the provisions of Section 4.2 (iv) of the Policy, which stipulates that women's access to financial services should increase by at least 15 per cent annually to eliminate gender disparity, 60 per cent of the Fund has been earmarked for providing financial services to women.

\subsection{Statement of the Problem}

Micro, Small and Medium Enterprises (MSMEs) form the fundamental pool that provides a lot of opportunities for employment and economic growth. There employ thousands of individuals in the primary and secondary sectors, thereby reducing the weight of unemployment on the nation. However, developing a sustainable source of finance for MSMEs has remained a perennial problem, partly due to poor accounting system and lack of collateral security.

In traditional debt finance, the extension of the credit is primarily based on the overall creditworthiness of the firm and the lender considers the expected future cash flow of the firm as the primary source of repayment (OECD, 2015). However, the techniques to assess and monitor the firm's creditworthiness, thus addressing the problem of information asymmetry between lender and borrower, may vary significantly. Different lending technologies combine different sources of information about the borrower, screening and underwriting procedures, structure of the loan contracts, monitoring strategies and mechanisms. The literature distinguishes transaction lending, based primarily on 'hard' quantitative data, and relationship lending, largely based on 'soft' qualitative information (e.g Berger and Udell, 2002, 2006). Under the first category are: i) financial statement lending, which depends on the availability of informative and audited financial statements on the side of the borrower and thus applies to informationally transparent borrowers, and; ii) small business credit scoring, which, on the other hand, may be applied to informationally opaque SMEs, as much of the information concerns the personal history of the owner, rather than the enterprise. In the case of relationship lending, information is gathered directly by the loan officer through contact over time with the enterprise, the entrepreneur and the local community, and by observing the SMEs' performance on all dimensions of its banking relationship, including loan contracts, deposits and other 
financial products. The loan officer may often remain the proprietor of the soft information, as this may not be easily observed and verified by others. This gives rise to agency problems, which may be better addressed by small banking organisations with few managerial layers and closer coordination between the management and loan officers (Berger and Udell, 2002; Stein, 2002). Also, small banks are often headquartered closer to potential relationship customers, reducing problems associated with transmitting soft information from loan officers to senior management. In fact, greater hierarchical and/or geographical distance between the information collecting agent and the loan approving officer may lead to less reliance on subjective information and more on objective information (Liberti and Mian, 2009).

Specific challenges limit traditional bank lending to SMEs. These are largely related to the greater difficulties that lenders encounter in assessing and monitoring SMEs relative to large firms (OECD, 2006, 2013). First, asymmetric information is a more serious problem in SMEs than in larger firms. SMEs often do not produce audited financial statements that yield credible financial information and have no obligation to make public disclosure of their financial reports, although they are generally obliged to produce them and make them available to relevant authorities upon request. Furthermore, in smaller enterprises, the line of demarcation between the finances of the owner(s) and those of the business is usually blurred. Unlike established public companies, which are expected to observe standards of corporate governance with clearly defined roles for shareholders, managers and stakeholders, SMEs tend to reflect the idiosyncrasies of their owners and their informal relationships with stakeholders. Hence, the entrepreneur has better access than the financier to information concerning the operation of the business and has considerable leeway in sharing such information with outsiders. The implications of asymmetries in information are made more severe by the large heterogeneity in the SME sector. SMEs are characterised by wider variance of profitability and growth than larger enterprises, and exhibit greater year-to-year volatility in earnings (OECD, 2006). Invariably, many studies have investigated the impact of Development Finance on the growth of the Nigerian economy, but only little attention has been given to its impact on the growth of MSMEs in Nigeria. Thus, this study investigates the Implications of Development Bank Financing on the growth of Micro, Small and Medium Enterprises in Nigeria.

\subsection{Research Questions}

This study is set to answer the following empirical questions:

1. How adequate are the accounting practices of MSMEs?

2. To what extent does the MSMEs access to finances depend on their accounting practices in Nigeria?

3. To what extent do credits to MSMEs depend on the availability of collateral?

\subsection{Hypotheses of the Study}

The relevant hypotheses for this study as stated as follows:

$\mathbf{H}_{\mathbf{0}} \quad$ MSMEs in Nigeria do not have poor accounting practices

$\mathbf{H}_{\mathbf{0}}$ MSMEs' access to finance in Nigeria does not depend on their accounting practices.

$\mathbf{H}_{\mathbf{0}} \quad$ Financial assistance to the MSMEs does not depend on availability of collateral.

\subsection{Conceptual Review}

\subsubsection{The Concept of Small and Medium Enterprises}

The concept of SMEs is dynamic and relative (Olorunshola 2003, Ogunleye 2004). Several institutions and agencies defined SMEs differently with parameters such as employee's size, asset base, turnover, financial strength, working capital and size of the business. These definitions include; Nigerian Industrial Policy 1989 defined SMEs as enterprise whose investment in working capital is between N100,000 and N2m excluding cost of land. CBN Monetary Policy Circular No. 22 of 1998 defined SMEs as any enterprise whose investments include land and working capital is less than 300,000 and annual turnover is less than 
N5m. The Nigerian Industrial Development Bank (NIDB) also defined small enterprise as an enterprise that has investment and working capital not exceeding N750,000 and medium enterprise as one with N750,000 to N3m. The Federal Ministry of Industry Guidelines to NBCI also defined as business with a total cost not exceeding N500,000 (excluding cost of land but including working capital). Centre for Industrial Research and Development (CIRD) of the Obafemi Awolowo University, Ile-Ife defined SMEs as an enterprise with capital base not exceeding N25,000 and employing capital base not exceeding N250,000 and employing on full time basis, 50 workers or less. Also, according to NERFUND, SMEs is an enterprise that has its investment to be less $\mathrm{N} 10 \mathrm{~m}$ excluding the cost of land. Nigerian Bank for Commerce and Industry (NBCI) defined SMEs as business with total capital not exceeding N750,000 (excluding cost of land but including working capital).

Another definition of SMEs that worth adopting is that of that National Council on Industry which in 1992 streamlined the various definitions of SMEs and agreed to change it every 4 years. It defines SMEs as enterprises with fixed assets above N1m but not exceeding N10m, excluding working capital while medium scale as enterprises with fixed asset that is more than $\mathrm{N} 10 \mathrm{~m}$ and less $\mathrm{N} 40 \mathrm{~m}$ including working capital but excluding cost of land in 1992, then in 1996, it defined small scale business as enterprises with more than $\mathrm{N} 1 \mathrm{~m}$ but less than N10m excluding cost of land and including working capital and a labour size of between 11 and 35 workers while medium scale enterprises should have over $\mathrm{N} 40 \mathrm{~m}$ and less than $\mathrm{N} 150 \mathrm{~m}$ as fixed asset including working capital and excluding cost of land and labour size should be 36 and 100 working (Olorunshola 2003). New Industrial Policy for Nigeria defined SMEs as enterprises with total investment of between N100,000 and N2m excluding cost of capital but including working capital (Guidelines for the Small- Scale Industries Investment Scheme 2001 cited in Ogunleye 2004). The National Council on Industry (NCI 2001) offered the following definitions for micro, small- and large-scale enterprises in Nigeria.

The above definitions show that there is no universal definition of SMEs however, for the purpose of this write up the definition of SMEs according to SMIES can be adopted which defined SMEs as establishment with less than $\mathrm{N} 20 \mathrm{~m}$ (exclude cost of land and working and has more than 10 employees and less than 300 employees.

\subsubsection{Characteristics of SMEs}

The peculiar characteristics of SMEs have helped in enhancing their performance in the economy. By their nature, SMEs constitute the most viable and veritable vehicle for self-sustaining industrial development. They possess common capability to grow an indigenous enterprise culture more than any other strategy (Udechukwu 2003). Adeleja (2005) enumerated the following as the peculiar attributes of SMEs; creativity, provision of inputs and or material components for large enterprises, mainly found everywhere especially in the local communities and fasted tools for job creation. Olorunshola (2003) in his work, identified simple management structure result from the fusion of ownership and management by one man as another characteristic of SMEs. According to (Udechukwu 2003) SMEs are characterized by labour intensive production processes, centralized management, have limited access to long term capital, use local resources, and closely attached to the products that launched them. The peculiarity of SMEs in enhancing economic development can be best described in this statement; SMEs constitute the most dynamic segment of many transitions and developing economies. They are more innovative, faster growing, family/individual ownership and subjective in decision making and possibly more profitable as compared to larger sized enterprises (World Bank 2001, Ogunleye 2004).

\subsubsection{Contributions of SMEs to Economic Development}

The contributions of SMEs to economic development of both developed and less developed countries have been obvious in these nations' GDP, industrial output, employment, poverty alleviation and export promotion. Statistically, the 
Nigerian GDP by sector shows that agriculture contributes about $32 \%$, industry $41 \%$ and $27 \%$ (Weller et al 1999). In most cases, of the industry figure, SMEs usually dominate all other sub-sectors. For instance, in Japan, $80 \%$ of the total industrial labour force belongs to SMEs sector, $50 \%$ in Germany and $46 \%$ in USA are employed in SMEs. In USA, SMEs contribute nearly 39\% to their national Income (Udechukwu 2003). Also, in less developed countries such as Nigeria, India, Indonesia, Mali etc., SMEs have been identified to constitute more than $95 \%$ of establishments in the organized manufacturing sector and have become a vibrant core sub-sector making substantial contribution in terms of employment generation and industrial output and export. This means that SMEs play important role in the economies of both developing and developed countries.

In USA, statistically the total enterprises registered as SMEs account up to $22 \mathrm{~m}$ of the total enterprises and they generate more than $1 / 2$ of the country's GDP, employing more than $53 \%$ of the total private workforce. In China, the number of SMEs increased from $1.52 \mathrm{~m}$ in 1978 to $19 \mathrm{~m}$ in 1991 and the number of people employed by them also increased from $28 \mathrm{~m}$ to $96 \mathrm{~m}$. In Iran, SMEs contributed up to $6.2 \%$ of the nation's industrial output and more than $75 \%$ of total employment in 1996. In Israel, SMEs recorded for $9.7 \%$ of the nation's enterprises in 1996 , employing up to $50 \%$ of the country's workforce. The country recently assisted over 50,000 people in establishing their own business. India also experienced the contribution of SMEs in their economic development recording a total of $3.1 \mathrm{~m}$ as enterprises classified under SMEs in the period of 1998-1999. The SMEs contribution in India can be classified as 95\% of the total industrial units, $40 \%$ of the total industrial output, $80 \%$ of employment in the industrial sector and $35 \%$ of the total export of the country (Ogunleye 2004). This information was adopted from Ogunleye 2004.

\subsubsection{Government Schemes and Institutions for Financing SMEs}

To ensure that funds are available to SMEs operators, the federal government has since 1970s continued to play pioneering and active roles in financing and stimulating the Nigerian SMEs. Ogunleye (2004) identified these roles to include provision of strong institutional support, ensuring easy access to credit facilities at reasonable rates, provision of industrial banks, provision of continuous training and research and provision of enablement monetary and fiscal policies. To harness these efforts, quite a number of institutions and schemes have been established to ensure that these objectives are fulfilled. These schemes include;

\subsubsection{Central Bank of Nigeria's Support and Schemes for SMEs Financing}

The SMEs as the bedrock of the industrial development have some many advantages which have been mentioned to include means of employment for both skilled and unskilled labour, serving as training grounds for entrepreneurs, provision of local materials for large scale industrials etc. Moreover, if well managed, the SMEs can gradually transform into the giant corporations of tomorrow. These contributions thus explain why Governments, local and International agencies mobilize efforts towards the realization of sustainable industrial growth and the creation of mass employment through the rapid growth and development of the small-scale enterprises. However, the SMEs have had limited access to institutionalized credit facilities, due to factors such as; risky of the business, the biasness of the financial and other lending institutions in extending credit to SMEs operators, inability to keep up to date accounting records for the business, inability to provide collateral security and so many other challenges. In recognition of these constraints and in order to ensure the realization of the potential benefits of virile SMEs in the economy, the Central Bank of Nigeria has remained committed to the growth and development of the small and medium scale enterprises in Nigeria. This stance has been successively reflected in the Bank's policies over the years. In particular, the CBN has through its credit guidelines over the years, and until very recently, required the erstwhile commercial and merchant banks to allocate stipulated minimum of credit to the preferred sectors including the SMEs.

For instance, in 1979/1980, the CBN stipulated $10 \%$ as a minimum total credit for indigenous borrowers with SMEs inclusive. This figure was increase to $16 \%$ and $20 \%$ of total loans and advances in 1980 and 1989 , respectively. Where any bank default, the same percentage figure will be deducted at source from the 
bank's deposits with the CBN and such amount will be given to the sector in question through one of the development banks. Due to the CBN stringent measures on the defaulting banks, majority of the banks were forced to comply with the stipulation, and this resulted to improvement in the banks' lending to the SMEs sector. Evaluating the performance of the banks' lending to the SMEs, statistically, a total aggregate credit of N23.9 billion was disbursed to SMEs in 1992 which represents $45.1 \%$ of the total loans and advances, this figure rose to N41.5 in 1995 and to N177.1 billion in 1997 representing $24.2 \%$ and $16 \%$ of the total banks loans and advances in 1995 and 1997 respectively. In 1993, the liberalization of the financial sector as one conditions of the use of the open market operations as the major policy instrument for CBN financial control, also helped in making SMEs to remain the force in credit allocation till 1996. The CBN, apart from this also used the following financial support initiatives and schemes in their effort to ensure that SMEs receive a fair treatment as long credit allocation is concerned. Some of these schemes include;

\subsubsection{The National Economic Reconstruction Fund (NERFUND)}

The inception of SAP in 1986 which resulted to the devaluation of the Naira worsened the SMEs access to financial institutions credit for both start-up capital and capital for expansion of their businesses. The Federal Government in collaboration with the CBN in January 1990 established the National Economic Reconstruction Fund (NERFUND), purposely to bridge the resource gap between SMEs and the financial institutions. The main purpose of establishing NERFUND is to provide relatively long-term loans (of period between 5-10 years), to SMEs at a reduced rate of interest so as to enhance the SMEs development for economic growth and development. Record shows that by 1990 and 1998, NERFUND had disbursed US\$144.9 million (Foreign Exchange) and N681.5million (Naira) to finance 218 projects.

However, since its inception, NERFUND activities have been constrained mainly by the devaluation of the Naira coupled by the inability to service the loan by the borrowers. By 2001, NERFUND, the Nigerian Bank for Commerce and Industry and the Nigerian Industrial Development Bank were merged to form the Bank of Industry (BOI).

\subsubsection{World Bank-Assisted SME II Loan Project}

In order to further expand credit allocation to SMEs, the Federal Government in collaboration with World Bank agreed in 1989 to complement other sources of funding the SMEs. In line with this, a loan facility of US\$270 million, was to be made available for lending to SMEs through eligible participating banks. The $\mathrm{CBN}$ in order to administer the credit components and other related activities of the World Bank loan were administered in 1990 established an SME Apex unit so as to facilitate the project proper implementation. The SME apex unit before it stopped has approved a total of 211 projects valued at US\$132.8 million between 1990 and 1994. As at June 1996, records show that a total of US\$ 107.1 million has been disbursed resulting to the establishment and modernization of 102 projects.

\subsubsection{Rural Banking Scheme}

Rural Banking scheme was established in 1977 purposely to solve the rural underdevelopment and inadequacy of credit to the agricultural sector for the rural based small-scale industries. As a result of the establishment of this scheme the commercial banks in Nigeria were mandated to establish their branches in the rural areas in Nigeria. A total of 756 new rural bank branches were recorded to would had been established by 1989 with a total deposit in all the rural branches amounting to about N5.7 billion.

\subsubsection{People's Bank of Nigeria}

In October 1989, the federal Government commissioned the People's Bank of Nigeria (PBN) with the primary objective of ensuring that the credit needs of the micro and small enterprises are met. Evaluating the activities of the PBN, in the process of meeting up with its target of 170 branches, it was evidence that by 1993, the bank had already been extended to all the states of the federation. A strategy of lending to groups of entrepreneurs rather than individuals was adopted as a deliberate policy based on the "peer pressure" concept. 


\subsubsection{Community Banks}

Community Banks were established in 1991 by the CBN mainly to; the promotion of rural Development through the provision of financial and banking services to communities that have not been adequately supplied with such services. To ensure that the objective of the community bank is accomplished, it was meant to come under the surveillance activity of the Central Bank of Nigeria and their activities are therefore receiving adequate guidance from the CBN.

\subsubsection{The Nigerian Industrial Developmental Bank Ltd (NIDB)}

The Nigerian Industrial Developmental Bank was established to lend long-term loans for investments in industrial activities. To ensure that the SMEs benefit from the service of NIDB, special units were established which focused on rendering financial assistance to them. NIDB has a unique feature that it should have equity participation in the paid-up share capital of the company which is financing. Nigerian Industrial Development Banks were able to disburse a total sum of N174.6m, to Small and Medium enterprises during the period of 1980 -1988. For the effectiveness of NIDB, it was merged with others financial institutions that operate in the same class with the bank to form bank of Industry.

\subsubsection{The Nigerian Bank for Commerce and Industry (NBCI)}

In order to provide financial services to the indigenous business community in SMEs The Nigerian Bank for Commerce and Industry (NBCI) was established in 1973. The NBCI administered the SME I World Bank loan scheme as an apex financial body for SME and between 1973 and 1986, the NBCI approved 797 projects that valued at N965.5million and a total of N141.82 million was also disbursed between 1987 and 1988. The bank also financed projects under the World Bank loan scheme and a total of 126 projects were financed. Just like other financial institutions, the NBCI encountered administrative and operational problems, which frustrated its major objectives and led to restructuring of the bank to form part of the BOI.

\subsubsection{Agricultural Credit Guarantee Scheme Fund}

To facilitate the accessibility of credit to the agricultural sector, in 1978, the Agricultural Credit Guarantee Scheme was introduced. For the effective administrative of the scheme, a lump sum amount of N100 million was provided to be subscribed to by the Federal Government and the CBN at the ratio of $60 \%$ and $40 \%$ respectively. To ensure that there was enough coverage by the scheme, this figure was increased to N3. billion in 2001. The ACGSF was mainly for the provision of guarantee in respect of loans granted by the commercial and merchant banks with regard to agricultural purposes to increase the level of the bank credit to the agricultural sector. To ensure that the money collected was not misused by the borrowers, it was agreed that the scheme should settle the suppliers directly where the loans are used to purchase livestock, machinery or farming equipment and the supplier will be made to send a document to the bank as evidence that the items for the borrower have been duly delivered. Since its inception, the scheme has made an impact as long as credit extension to the Agricultural sector is concerned and over N3.3billion had so fund be granted to different beneficiaries.

\subsubsection{Nigerian Export Import Bank}

In order to provide finance, risk mitigating facilities and trade information as well as advisory services to Nigerian SMEs exporters, in 1991 the Nigerian Export-Import Bank (NEXIM) was established. The NEXIM's Rediscounting and Refinancing Facility was introduced, to assist banks to provide pre and post shipment finance in support of non-oil exporters. In summary, though the schemes and programmes which were put in place to find solutions to the problems of credit delivery to the SME have achieved considerable successes, there still exists a huge gap which should be filled. The need to reduce the credit risks on loans to SMEs by the financial institutions has become more pronounced given the extremely slow rate of draw down on facilities like the World Bank- assisted SME 11 loan and NERFUND. In its analysis, the technical committee for the establishment of a National Credit Guarantee Scheme for Small and Medium Enterprises (SMEs) in Nigeria, established that not more than 50 percent of aggregate effective demand for investment 
loans in the manufacturing sector are currently being met. This therefore, necessitates further action aimed at enhancing the flow of financial resources to the SME sub - sector.

\subsubsection{Other SMEs Financing Initiatives that are More Recent}

In order to make the SMEs sector more vibrant, the Central Bank of Nigeria evolved new initiatives, which are geared towards improving accessibility and availability of credit to the SMEs through the following schemes:

\subsection{The Small and Medium Industries Equity Investment Scheme (SMIEIS)}

Bothered by the persistent decline in the performance of the industrial sector and with the realization of the fact that the small and medium scale industries hold the key to the revival of the manufacturing sector and other productive sectors of the economy, the Central Bank of Nigeria successfully persuaded the Bankers' Committee in 2000 to agree that each bank should set aside 10 per cent of its annual profit before tax for equity investment in small and medium scale enterprises. To ensure the effectiveness of the programme, banks are expected to identify, guide and nurture enterprises to be financed under the scheme. The activities targeted under the scheme include agro-allied, information technology, telecommunications, manufacturing, educational establishments, services, tourism and leisure, solid minerals and construction. The scheme was formally launched in August 2001. With the introduction of the scheme, it is expected that improved funding of the SMEs will facilitate the achievement of higher economic growth. As at August 2002 , the sum of $\$ 11.572$ billion had been set aside by 77 banks. Out of this amount, N1.692 billion had been invested in the small and medium scale enterprises.

\subsection{Nigerian Agricultural, Cooperative and Rural Development Bank (NACRDB)}

Nigerian Agricultural, Cooperative and Rural Development Bank (NACRDB) was established in October 2000 as an amalgamation of the Peoples Bank of Nigeria, Nigerian Agricultural and Cooperative Bank and the Family Economic Advancement Programme (FEAP). The primary aim for setting up this scheme is to finance agriculture as well as small and medium enterprises. It is structured to accept deposits and offer loans /advances in which the interest rates are usually in proportion to the reason for taking the loan mainly for to Nigerians and their business. Other services offer by the NACRDB include target savings; Loan for start - up ventures and smallholder loan schemes.

\subsection{The Bank of Industry}

The Bank of Industry (BOI) was set in 2000 as an amalgamation of the former Nigerian Industrial Development Bank, the Nigerian Bank for Commerce and Industry and the National Economic Reconstruction Fund (NERFUND). The main objective for setting up BOI is to provide credit to the industrial sector, including the SMEs.

\subsection{Refinancing and Rediscounting Facility}

This programme was introduced by the Central Bank of Nigeria in January 2002 to offer financial assistance to at concessionary interest rate to support medium to long term bank lending to the real sectors of the economy. The primary objective of this programme is to provide liquidity to banks in support of their financing of the productive sector activities of Nigerian economy. This was meant to bridge the gap in financing projects that are mainly long term since banks mainly gives short term loans and loans for commerce and trade. The medium- and long-term business operators, who are involved in productive sectors of the economy, are to be encouraged through this facility. Banks that are facing liquidity problems as a result of having committed their resources to long term financing to the specified productive sectors are relieved through the activities of RRF. The following sectors are included for the RRF loan schemes; agricultural production, semi manufacturing and manufacturing, solid minerals and information technology. Under the facility, banks shall have access up to 60 percent of qualifying loans. Qualifying loans must have been held for not less than one year. 


\subsection{Historical Development and Orientation of Small-Scale Industries in Nigeria}

Small scale industry orientation is part and parcel of Nigeria. Evidence abound in our respective communities of what successes our great grandparents made of their respective trading concerns, yam barns, iron smelting, farming, cottage industries and the likes. So, the secret behind their success of a selfreliant strategy does not lie in any particular political philosophy, so much as in the people's attitude to enterprise and in the way by which the right incentive is adequate enough to make risk worth taking are provided. Economic history is well stocked with enough insights into the humble beginnings of presentday grand corporations. Evidences abound that almost all of the multinational giant corporations were cottage enterprises, growing as their industry grew, and through their own sheer ability either reproduce existing products more cheaply or improve their ability. Even at the international level, in the early stages of her industrialization, Japan's economy was dominated by traditional industries, cottage firms, and by a large number of small-scale firms, drawing their strength not from abundance of capital but rather from her supply or labour. Back home in Nigeria, the respective government policies accorded and gave priority to the country's small-scale enterprises. This has been in recognition that they constitute the fountain head of vitality for the variation economy and consequently their problems have been viewed as those of the nation, by virtue of their number, diversity, penetration in all sectors of production and marketing, contribution to employment and to the prosperity of the particular areas in which they operate. In concrete terms, small scale industries constitute a greater percentage of all registered companies in Nigeria, and they have been in existence for quite a long time. Majority of the small-scale industries developed from cottage industries to small enterprises and from small scale to medium and large-scale enterprises (Basil, 2005).

\subsection{The Importance of Small and Medium Enterprises in Economic Development}

Among the significant roles played by the SMEs are as follows:

First, the SMEs provide the training ground for the development and growth of indigenous entrepreneurs. They serve as vehicles for the propagation and diffusion of innovative ideas for far reaching dimensions. They are more flexible and can easily adapt to changes in the external environment. A second social contribution of SMEs according to Basil (2005) is the transformation of traditional industry. In both developed and developing countries, the traditional sector has served and continues to serve as the springboard for launching into a vibrant modern sector. Thus, a fledging SMEs sector can be a means of achieving a smooth transition from the traditional to the modern industrial sector (United Nations, 1984). Third, SMEs due to their labor intensity and usage of low-level technology are able to garner and use the widely available local labor supply. SMEs assist in the dispersal of economic activities through encouraging the development and modernization of these activities outside the major metropolitan areas. Thus, they are able to stem the tide of rural-urban drift. Another economic role of the SMEs is their ability to mobilize financial resources, which would otherwise be idle or untapped by the formal financial sector (Iornem 2000). Fifth, SMEs facilitate the conservation of foreign exchange and the development of the scarce resources of management in developing countries. This is mainly due to their size or scale of operations and unsophisticated management structure. A high percentage of the profit of SMEs, most of which are locally owned is known to be ploughed back to ensure a higher rate of future growth and that the SMEs provide the desired linkage effects, especially agro-industrial linkages. It is pertinent to highlight the contributions of SMEs to the economics of some countries and, that of Nigeria. A study carried out by the Small Business Research Unit in the United Kingdom between the periods 1982-1988, showed that SMEs created between 800,000 and 1,000,000 new jobs. Also, Gibb (1996) opined that small and micro enterprises were by far the most common form of enterprises in Europe and constitute over $98 \%$ of all registered Companies. In Japan, the industrial strength of the nation is premised on SMEs. They employ more than $82 \%$ of the total labour force and account for more than $50 \%$ of the total manufacturing value added. In Nigeria, the SMEs have through BOI assisted projects and created a lot of jobs (Iornem, 2000) 1.5 Small and Medium Scale Enterprises in Nigeria The Nigerian industrial scene is characterized by a wide diversity of industrial structures, technologies, factor intensities, input requirements and product qualities. Also, the industrial scene shows different levels of organization, administration/managerial and technical 
skills. This is because Nigeria adopted the classical approach to industrialization. However, the industrial development of the 1960s and 1970s concentrated on Large Scale Industries (LSI). These industries subscribed to by the government and foreign multi-nationals had a dramatic downturn in the early 1980s as a result of the collapse of the oil boom. The reduction in the foreign exchange allocated for the importation of raw materials and spare parts for these LSIs, led to the general shut- down or reduction in capacity utilization of these firms between 1983 and 1996. Accompanying this economic downturn was massive retrenchment by the industries, scarcity of basic goods and services and the subsequent devaluation of the nation 's currency (the Naira). The above economic scenario led to the adoption of the Structural Adjustment Programme (SAP) in 1986 and a change in the industrial policy in 1988. This change shifted the priority focus from LSIs to SMEs. The change was highly necessary. According to Iornem (2000), the biased strategy towards large scale production activities invariably undermined the growth and development of indigenous industries most of which are small and medium scale in sizes. The public sector preoccupation with public sector investment led to the neglect of and inadequate attention to development of infrastructural facilities - roads and railways, water and human resources development, telecommunications and lastly electricity and other energy supplies. Also, the SMEs are widely accepted as having greater capacities to utilize locally available raw materials, technologies, manpower and promote even and balanced industrial development. The major activity in the SMEs development occurred between 1987 and 1989 with the establishment of several institutions to provide financial assistance to small and medium enterprises. Such institutions include: The Nigeria Industrial Development Bank, the Nigerian Bank for Commerce and Industry, Nigerian Agricultural and Cooperative Bank and the National Economic Reconstruction Fund (NERFUND). However, by the mid- 1990s, the funds being made available by these institutions had dried up and most of the SMEs had collapsed as a result of the debt burden (Inflated foreign exchange) and the value of the Naira. In addition to the above, the contributions made by the SMEs to the economy were low. The above scenario necessitated the formulation of new policies and attitudes towards the growth and development of SMEs in Nigeria.

\subsection{SMEs in Nigeria}

In Nigeria, empirical report shows that an estimate of about $70 \%$ of the industrial employment is held by SMEs and more than $50 \%$ of the Gross Domestic Product is SMEs generated (Odeyemi, 2003). Given the seminal role of SMEs to the economy of Nigeria, various regimes of government since independence in the 1960 s, have focused on various programmes and spent immense amount of money with the primary goal of developing this sector, these have however not yielded any significant results as evident in the present state of the SMEs in the country (Mambula, 1997). SMEs are generally very susceptible and only a certain number of them manage to survive due to several factors such as difficulty in accessing credits from banks and other financial institutions; harsh economic conditions which results from unstable government policies; gross undercapitalisation, inadequacies resulting from the highly dilapidated state of Infrastructural facilities; astronomically high operating costs; lack of transparency and corruption; and the lack of interest and lasting support for the SMEs sector by government authorities, to mention a few (Oboh 2002; Okpara 2000; Wale-Awe 2000).

The situation is equally prevalent in the Nigerian economy where commercial banks often prefer to lend to government, trade in foreign exchange (FOREX), and financing buying and selling. A banker in Nigeria aptly put such preferences that "the banks are not a charity; hence why should they take risks with SMEs when they can make good money elsewhere". These preferences and tendencies of the commercial banks have worsened the lack of financing for SMEs which has also affected the economic growth. The Financial systems in every country play a key role in the development and growth of the economy, although the ability to play this role effectively and efficiently largely depends on the degree of development of the financial system. The traditional commercial banks which are key players in the financial systems of nearly every economy, have the potential to pull financial resources together to meet the credit needs of SMEs, however, there is still a huge gap between supply capabilities of the banks and the demanding needs of SMEs. In Nigeria, the situation is even more prevalent as noted by Olutunla and Obamuyi (2008). 
SMEs in Nigeria have not performed creditably well and hence have not played the expected vital and vibrant role in the economic growth and development of Nigeria. However, the role played by SMEs, notwithstanding their development, is everywhere constrained by inadequate funding and poor management. The unfavourable macroeconomic environment has also been identified as one of the major constraints which most times encourage financial institutions to be risk-averse in funding small and medium scale businesses (Ogujiuba, 2004).

Financial systems, the world over, play fundamental roles in development and growth of the economy. The effectiveness and efficiency in performing these roles, particularly the intermediation between the surplus and deficit units of the economy, depends largely on the level of development of the financial system. It is to ensure its soundness that the financial sector certainly the most regulated and controlled by the government and its agencies. (Allen 1994). SMEs play very important roles in developing economies and assisting them is a task which ranks high in the priorities of the governments. This position is corroborated by other studies which identified financial support as one of the main factors responsible for small business failures in Nigeria (Abereijo \& Fayomi, 2005; Okpara \& Pamela, 2007).

\subsection{Formal Sources of Financing SMEs}

The commercial banks, merchant banks, and development banks provide the formal sources of finance to SMEs. The financial system in Nigeria is not in short supply of liquidity, but banks have been very reluctant to grant loans to SMEs, which they regard as a high-risk sector. Most of the banks would rather pay the penalty imposed for not meeting the minimum exposure to preferred sectors of the economy than actually run the risk of being exposed to them. According to Ojo (1984), the sources of investment finance for SMEs include owner's savings and assistance from banks, government institutions, local authorities, cooperative societies, relatives and friends, and moneylenders. The study shows that almost all the funds came from personal savings (96.4\%) with about $3 \%$ from the informal sector and $0.21 \%$ from the formal financial institutions. This trend is further established by a 1983/84 study by the Nigerian institute for Social and Economic Research (NISER). NISER findings show that about $73 \%$ respondents raised their funds from personal savings, while only about $2 \%$ obtained their funds from the formal financial institutions.

SMEs are crucial catalysts for economic development (Aruwa, 2006). Banks provide a nation with a function of pooling scattered resources from surplus to deficit units so as to promote investment innovation, productivity and consequently growth and development. The banking industry in Nigeria dominates the financial system (Agusto, 2000). Berger (2001) maintains that a well-functioning financial system contributes to investment and economic growth. Every enterprise at its onset, before standing firm on its feet, needs borrowing. The first place that they need to go and borrow at those times is the banks. According to elementary corporate finance theory, an investment project should be undertaken whenever its net present value is positive. This assumes that the capital outlay is not exhaustive. Firms do any volume of investment, and so where the firms do not have adequate capital to embark on any level of investment, there is need for capital borrowing (Mainoma, 2005).

This shows that even if an enterprise is strong and firmly rooted, it still does not stop borrowing, because it can embark on a very large-scale investment more than it currently does, if it can get the required capital. When funding becomes a major problem for such enterprises, nothing else works. This is because other problems which emerge later in an enterprise's lives that are being tackled as natural problems which come after its funding. This in turn hinders the growth and development of the economy. Njoku (2007) postulates that to forestall the imminent capital flight from the real sector to the banking sector, banks should begin to take second look at the industrial sector in terms of lending operations. He continues that banks should plough back a large proportion of the money available to them to the real sector of the economy as longterm loans at rates not exceeding $5 \%$.

The author further states that this will encourage industrialists not only to remain in their present businesses but also to achieve their business expansion targets. Small and medium scale enterprises dominate the private sector of the Nigerian economy, but almost all of them are starved of funds (Mambula, 2002). The 
persistent lack of finance, for establishment and operation of SMEs occasioned by the inability or unwillingness of the deposit money banks to grant long term credit to operators of the real sector of the economy, led to the establishment of development finance institutions and the introduction of numerous funding programmes for the development of SMEs in Nigeria. In spite of these institutions and funding programmes, there continues to be a persistent cry against inadequate finance for the development of the SMEs in the country. The CBN (2008) shows that commercial and merchant banks loans and advances to SMEs have been decreasing over the years. The statistics show thus; commercial bank's loans to SMEs as a percentage of total credit decreased from $48.8 \%$ in 1992 to $22.22 \%$ in 1994 . The trend increased marginally to $22.9 \%$ and to $25.5 \%$ in 1995 and 1996 , respectively. There was a sharp reduction from $25 \%$ to $17 \%$ in 1997 , and the decrease continued till it reached $0.2 \%$ in the year 2008 . Similarly, merchant banks loans to SMEs as a percentage of total credits reduced from $31.2 \%$ in 1992 to $9.0 \%$ in 2000 (Akabueze, 2002). The continuous decrease in commercial and merchant bank's loans to small scale enterprises can be attributed to lack of collateral from the SMEs to secure the loans and the high lending rates from the banks.

\subsection{Government intervention in SME financing (Nwosu, Chioma, and Emeka, 2017)}

In an attempt to improve the operational performance of the SMEs and aid their development, the government, post-independence, established various schemes such as Industrial Development Centers (IDCs) in 1962, Small Scale Industries Credit Scheme (SSICS) in 1971, Small Scale Industries Fund (SSIF). The government issued policy initiatives aimed at addressing the peculiar needs of the SMEs through existing commercial banks. Such among others include:

$>\quad$ The Rural Banking Scheme (1977);

$>\quad$ National Economic Reconstruction Fund (NERFUND) was established in the mid-1980s to assist SMEs to adjust to the Structural Adjustment Programme. The Fund provided a long-term loan support (510 years) to SMEs at concessionary interest rates;

Established the community banking scheme in 1991 with the objective of rural development and providing start-up facilities for smallholders; $\square$ Establishment of Bank of Industry (BOI) with the principal objective of providing credit to the industrial sector including SMEs at an interest rate of 10 percent;

$>\quad$ The Nigerian Agricultural Cooperative and Rural Development Bank (NACRDB) were also established with the objective of financing the rural sector with particular interest in the SME sub- sector;

$>\quad$ The Community Banking Scheme (1992) which gave mandates to commercial banks to provide finance to the SMEs. These initiatives failed mainly because of political instability, lack of fiscal discipline, inconsistent macroeconomic policies, by the government who established them. Despite the failures of most of the initiatives mentioned above, the need to put in place a policy framework that will help promote the development of a robust SME sector remains ever-present. These issues necessitated the formulation of new policies and attitudes towards the growth and development of SMEs in Nigeria. The schemes include:

\subsubsection{Small and Medium Enterprises Equity Investment Scheme (SMEEIS)}

This scheme commenced operation in 2001, under the supervision of the CBN. The objective of this scheme was to facilitate finance and management expertise to small and medium scale industries in Nigeria. Banks were to set aside 10 percent of their Profit after Tax annually in support of equity investment in small and medium enterprises. The arrangement eliminates the interest burden and other associated charges on SME financing. This innovative Scheme affords SMEs access to long-term funding, disciplined approach to business and management as well as the opportunity to integrate into the formal financial sector among others.

\subsubsection{Small and Medium Enterprises Credit Guarantee Scheme (SMECGS)}

The Small and Medium Enterprises Credit Guarantee Scheme (SMECGS) was introduced in April 2010 to fast-track the development of the manufacturing and SME sub-sector by providing 80.0 percent guarantee 
for bank credits. The purpose of the intervention is to create more jobs and to provide N100 million maximum loan facility with five (5) years tenor for each project. As at end-September 2017 the total number of applications guaranteed from inception was 88 (Eighty-eight), valued at N4.251 billion. Also, cumulatively, the total number of fully repaid loans stood at 40 valued N2.228 billion since inception to date.

\subsubsection{N200 Billion Refinancing/Restructuring Facilities to Small and Medium Enterprises/Manufacturing (RRF)}

The Scheme was introduced in April 2010 to fast-track the development and revitalisation of ailing SMEs in the country through refinancing and restructuring of Deposit Money banks' (DMBs) existing loan portfolio. The facility has a tenor of 15 years and an annual interest rate of 7.0 percent repayable quarterly. From the inception of the program to end-September, 2017, the cumulative disbursements to clients through the Bank of Industry (BOI) stood at N381.99 billion in respect of 604 projects. Also, a total of N186.542 billion has so far been repaid by the DMBs. A total of 344 projects valued $\$ 85.148 \mathrm{bn}$ have so far been fully liquidated under the Scheme from inception to date (CBN, 2017).

\subsubsection{Real Sector Support Facility (RSSF)}

The CBN had in November 2014 approved the establishment of an N300 billion Real Sector Support Facility (RSSF) to address the funding needs of large ticket SMEs in Nigeria. It is aimed at closing the short-term and high- interest financing gap for SME/Manufacturing and start-ups, as well as create jobs through the Real Sector of the Nigerian economy. Cumulatively, a total of ten (10) projects valued N35.581bn have so far been disbursed under RSSF. The cumulative repayment by the DMBs to CBN from inception to September 2017 under RSSF is $\$ 357.0 \mathrm{mn}$ (CBN, 2017).

\subsubsection{The Micro Small and Medium Enterprises Development Fund (MSMEDF)}

In recognition of the considerable contributions of the Micro, Small and Medium establishments (MSME) sub- sector to the Nigerian economy and the huge financing gap in the country, the CBN launched the MSME improvement Fund on August 15, 2013, with a share capital of N220 billion. Ten (10) percent of the Fund has been devoted to developmental goals while ninety (90) percent to commercial components to be released to Participating Financial Institutions (PFIs) at 2\% interest rate for on-lending to MSMEs at a maximum of $9 \%$ per annum. Eligible activities to be financed consist of the agricultural value chain, services, cottage industries, artisans, and any income generating business as can be prescribed by the CBN now and then. As at end-August 2017 the cumulative wholesale amount disbursed stood at N115.178 billion.

\subsubsection{N50 Billion Textile Sector Intervention Fund}

The Central Bank of Nigeria in a bid to resuscitate the Textiles Industry has put in place a N50 billion special mechanisms for the restructuring of existing facilities and provision of further facilities for textile companies with a genuine need for intervention. This was the result of the meetings between the Governor and owners of textile mills in Nigeria on August 7, and September 29, 2015. Among the resolutions reached were that the Textile Mills articulate the status of their BOI CTG Loans stating their outstanding loan balances, tenure, interest rate, interest payment and the assistance being sought from CBN. Cumulatively, the sum of N26.386 billion has been disbursed in favour of thirty-one (31) projects from inception to date (CNN, 2017).

\subsubsection{Establishment of Entrepreneurship Development Centres (EDCs)}

This initiative was aimed at developing strong SMEs that can complete globally and contribute to national growth and development. Three EDSs were established in Kano, Lagos and Onitsha. Three new EDCs in Maiduguri, Makurdi and Calabar were later established, followed by Kano, Ibadan and Umuahia, and one outreach Centre located in the Minna. Cumulatively from inception, 30,262 participants were trained out 
of the total target of 28,500. 23,592 jobs were created while 11,809 accessed a total of N2.595bn as loan to start their businesses (CBN,2017).

\subsection{Challenges to SME Financing Strategy in Nigeria}

SMEs have been fully recognized as the main engine of economic growth and a major factor in promoting private sector development and partnership. Some of the financing challenges they encounter include:

$>\quad$ Accessibility to sustainable funds has perennially constituted a hindrance to adequate funding of Small and Medium Enterprises (SMEs), leading to the premature collapse of these industries.

Majority of the SMEs do not keep records for fear of tax obligations. The prevailing corrupt tendency in Nigeria, which has permeated the fabric of the society including Nigeria entrepreneurs, has prevented most small and medium enterprises operators from keeping adequate records. This makes it difficult to translate general policy framework into efficient and sustainable intervention programmes for the benefit of the SMEs in the country.

$>\quad$ Most SMEs operators prefer to get the funds as a loan rather than an equity contribution. They are averse to going into partnership schemes with banks under the SMIEIS programme, thus, setting back most SMEs in the country.

A good number of SMEs in Nigeria are not aware of the existence of the different sources of funds for SME development; the incentives available for them, as well as how to source funds from banks.

$>\quad$ The poor governance structure is another factor preventing the small and medium enterprises from accessing funds easily from banks and other specialised financial institution.

\subsection{Empirical Review}

Given the significance of SMEs in economic growth and development, numerous studies have assessed the role of SMEs sector in light of various activities stimulating growth and development. For instance, Nagaya (2017) examines the impact of SMEs on economic growth using dataset for India and found that SMEs activities are growth enhancing through various channels like employment and poverty reduction. Correspondingly, Aremu and Adeyemi (2011) finds similar evidence that SMEs are vital agent in creating job opportunities and reducing poverty using trend data analysed with Ordinary Least Square (OLS). In another study for a sample of 45 countries conducted by Beck, Dunt and Levine (2005) show that there is a strong positive correlation between SMEs activities and output growth. This implies that SMEs are vital instrument for promoting growth and development. However, no link is found between SMEs, poverty and inequality.

Taiwo, Ayodeji and Yusuf (2012) in their study of the role of SMEs in promoting economic growth in Nigeria have revealed that there is strong nexus between SMEs activities and economic performance in Nigeria. Moreover, the study found that SMEs in Nigeria are faced with several challenges including financial constraints, high level of corruption and lack of training and capacity building which have hindered their smooth activities. Additionally, Chinweuba and Sunday (2015) investigate the relationship between SMEs and economic growth of Nigeria. Their findings reveal that SMEs activities are growth enhancing through expansion in output and other various means of survival. In the same vein, Motilewa, Ogbari and Aka (2015) established that SMEs are found to be engine of growth in Nigeria. They also state that such enterprises operate with multiple challenges including financial and managerial constraints. In another study for the economy of Pakistan by Nalini, Alamelu, Amudha and Motha (2016), they noted that SMEs are making significant role in promoting job opportunities and commodities for export. Availability of finance has been widely viewed as a problem to growth and development of SMEs particularly in developing countries. For instance, Bekele and Zekele (2008) and Jibir (2015) have examined the role of finance in the development of SMEs and found that smooth financing has a strong link with the running and growth of SMEs and can boost their performance. Furthermore, there are some studies that found no significant impact of SMEs on economic growth. For example, Cravo, Gourly and Becker (2009) find that SMEs activities are negatively correlated with the level of growth and development. They further assert 
that human capital embodied in SMEs may be more significant for promoting economic growth than the SMEs activities. Using time series data for Sri Lanka, Vijayakumar (2013) find an insignificant nexus between SMEs and growth and development of Sri Lankan economy. Also, Olukayode and Somoye (2013) investigate the impact of finance on entrepreneurship growth in Nigeria using endogenous growth framework, the results show that the finance, interest rate, real gross domestic product, unemployment and industrial productivity are significant to entrepreneurship in Nigeria. Afolabi (2013) evaluated the effect of SMEs financing on economic growth in Nigeria between 1980 and 2010. The study employed ordinary least square (OLS) method to estimate multiple regression models. The study reveals that SMEs output proxy by wholesale and retail trade output as a component of gross domestic product and commercial banks' credit to SMEs exert positive and significant impact on the economic development. Furthermore, Onakoya, Fasanya and Abdurrahman (2013) examine the impact of financing small scale enterprises on economic growth using quarterly time series data from 1992 to 2009 using OLS. The result shows that loan to small scale entrepreneurs have a positive impact on the economic performance.

Also, the role of SMEs in employment generation has also been acknowledged in the literature. Anthony and Arthur (2008) investigated the role of micro, small, and medium enterprises in the growth of per capita income in the United States, using database for firms in the formal manufacturing sector with fewer than 10, 20, 100, or 250 employees. Employing regression model, the result of the study shows a positive relationship between economic growth and the prevalence of firms of medium size or smaller $(250$ employees or less). However, they find only limited connection between growth and the prevalence of small or micro firms with fewer than 10, 20, or 100 employees.

Kadiri (2012) examines the contributions of small and medium scale enterprises (SMEs) to employment generation in Nigeria. The binomial logistic regression analysis was employed as tools for statistical analysis. The results show that SMEs has not impacted positively on economic growth partly due to poor financing and commitment from the government. Iyigun and Owen (1998) show a negative relationship between the level of economic development and the level of self-employment in the labour force. Carree, Van Stel, Thurik and Wennekers (2002) find a nonlinear relationship between economic development and entrepreneurship activities. Also, Beck, Demirguc-Kunt, and Maksimovic (2005) estimate the standard growth regression including the relative size of the SMEs sector in terms of employment and find a positive but not robust impact on economic growth for a cross-section of countries. Using similar approach, Audretsch and Keilbach (2004) and Mueller (2007) obtain a positive impact of measures of entrepreneurship on economic growth in the context of developed countries. In addition, there are some panel studies that investigate the role of SMEs in promoting growth and development. In this regard, Andre, Carree and Thurik (2004) investigate the contribution of total entrepreneurial activity in GDP growth for a sample of 36 countries and test whether this contribution depends on the level of economic development measured as GDP per capita. The result shows that entrepreneurial activity by nascent entrepreneurs and owner/managers of young businesses affects economic growth, but the effect depends upon the level of per capita income. In another cross country study, Ming-Wen (2010), uses a dataset covering thirty-seven countries including developed and developing countries to examine the contribution to economic growth from the SMEs sector spanning between 1960 and 1990. The findings reveal that small scale businesses contribute positively towards economic prosperity of a country. Also, it is observed from the study that, in pursuance of economic growth, SMEs in the high- income economies generally help in the promotion of entrepreneurship activities, whilst in the less-developed economies they contribute in terms of job creation to the people.

\subsection{Methodology}

This research uses the survey research design method for the collection and analysis of primary and secondary data in order to achieve the stated objectives. The primary data was obtained from a sample of SME-operators in Nigeria. Because of proximity and cost, this study population is limited to the number of SMEs in Kogi State. The population for the study is two thousand six hundred and eight-eight $(2,688)$ SMEs being the figure obtained from the latest survey of the Ministry of Commerce and Industry, Kogi State (Ministry of Commerce and Industry, 2017). The structured questionnaire method was extensively used by the study. A total of three hundred and fortyeight questionnaires were distributed using the stratified random sampling technique. Using the Taro Yamene's 
formula, a sample size of 348 was obtained. In order to ensure the reliability of the data collection process, testretest method was adopted. Econometric model was specified to explain the relationship between the variables using the group logit model (GLOGIT). Similarly, Ordinary Least Square (OLS) technique was used for the purpose of analysing the GLOGIT model. Granting that the model of this study was based on the theories of qualitative response regression models, this is the most suitable model for the study. Amemiya (1981), Aldrich (1984), Larry (1997) and Moghaddan and Hallie (2009), Ikem, Chidi and Titus (2013) have used the quality response regression models to achieve dependable results. Data is weighted to correct for hetroscedasticity (Gujarati, 2009).

The econometric model of the study is specified as follows:

Granting that the rate of Access to Credit is a function of the availability of quality accounting information, which in turn is a function of the level of accounting practice. However, other variables also determine credit accessibility: this is captured by introducing another variable in the model as the availability of collateral facility. The model can be represented as follows:

Access to Credit $=\mathrm{f}($ level of accounting practice and collateral facility) Through the cumulative logistic distribution function, this is translated into the Group Logit model (Glogit).

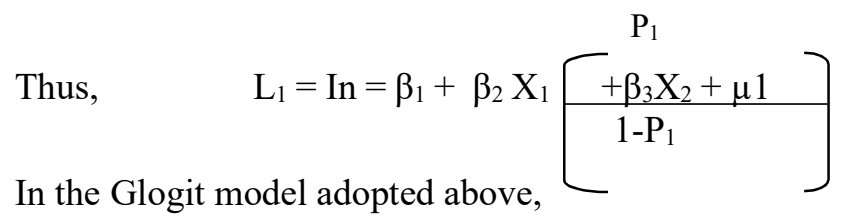

$\mathrm{P}_{1}=\mathrm{n}_{\mathrm{i}}$

$\mathrm{N}_{1} \quad$ (which represents the probability of accessing credit at ith level of accounting practice)

At each level of accounting practice, some SMEs access credit some don't,

$\mathrm{N}_{\mathrm{i}} \quad$ = those who access at ith level of accounting practice

$\mathrm{N}_{\mathrm{i}} \quad=$ total number of SMEs at each level of accounting practice

$1-\mathrm{P}_{1}=$ represent the probability of those who do not have access to credit at ith level of accounting practice

$\mathrm{P}_{1}=$ odd ratio in favour of accessing credit $1-\mathrm{P}_{1}$

In $\quad P_{1}$

$1-\mathrm{P}_{1} \quad=$ Log of the odd ratio in favour of accessing credit

$\mathrm{X}_{1}=\mathrm{ith}$ level of accounting practice by ranking

$\mathrm{X}_{2}=$ other requirements (specifically collateral facility). This is domiciled as follows: provide collateral $=1$, does not provide collateral $=0 . \beta_{1}, \beta_{2}$ and $\beta_{3}$ are coefficients and $\mu 1$ is the stochastic error term.

Table 1. Analysis and Interpretations

\begin{tabular}{|c|c|c|}
\hline Level of Accounting Practice by Ranking & $\begin{array}{l}\text { Number of SMEs in Each Level of } \\
\text { Accounting Practice }\end{array}$ & $\begin{array}{l}\text { Number who Access Funds at Each Level of } \\
\text { Accounting Practice }\end{array}$ \\
\hline 0 & 20 & 2 \\
\hline 1 & 151 & 15 \\
\hline 2 & 83 & 21 \\
\hline 3 & 36 & 11 \\
\hline 4 & 20 & 9 \\
\hline 5 & 0 & 0 \\
\hline 6 & 1 & 1 \\
\hline 7 & 0 & 0 \\
\hline
\end{tabular}

Source: completed by author. 
It could be seen from the above that the higher the levels of accounting practice the higher the proportion of SMEs who access loan from financiers. At 0 levels of accounting practice, $10 \%$ of the SMEs obtain loan (definitely, this must be those who are capable of providing collateral facility). We see that while $9.9 \%$ accessed fund at level 1,25\% accessed fund at level 2 . The increase continued as follows: $30 \%$ at level 3 , $45 \%$ at level 4, no SME is at level 5, 100\% at level 6 and no SME at level 7. Preliminary, we assert that the higher the levels of accounting practice the higher the accessibility of fund. We are yet to confirm this preliminary result from our GLOGIT model.

Table 2. Collateral Security and Accessibility of Fund

\begin{tabular}{|c|c|c|c|}
\hline $\mathrm{X} 1$ & $\mathrm{n} 1$ & Number who provide collateral & Dummy \\
\hline & & $2=100 \%$ & 1 \\
\hline & 2 & $19=67 \%$ & 1 \\
\hline 2 & 15 & $15=71 \%$ & 1 \\
\hline 3 & 21 & $15=45 \%$ & 1 \\
\hline 4 & 1 & $0=0 \%$ & 0 \\
\hline 5 & 9 & $0=0 \%$ & 0 \\
\hline 6 & 1 & - & 0 \\
\hline 7 & 0 & $0=0 \%$ & \\
\hline
\end{tabular}

Source: completed by author.

As an a priori statement, the researcher is confident to ascribe 0 to any level of accounting practice if $95 \%$ and above do not provide collateral to qualify for loans otherwise it will ascribe 1 . It is allowable in behavioural sciences to accommodate $5 \%$ chances of making mistakes. The table above shows that the few SMEs at very high levels of accounting practice do not provide collateral to qualify for most loans. This is shown at levels 4 and levels 6 respectively.

Table 3: Log of the odds, Levels of Accounting Practice and Collateral Facility

\begin{tabular}{|c|c|c|}
\hline $\mathrm{L}$ & $\mathrm{X}_{1}$ & $\mathrm{X}_{2}$ \\
\hline-0.994 & 0 & 1 \\
\hline-0.653 & 1 & 1 \\
\hline-0.371 & 2 & 1 \\
\hline-0.459 & 3 & 0 \\
\hline-0.725 & 4 & - \\
\hline-5 & - & 0 \\
\hline 0 & 6 & - \\
\hline
\end{tabular}

Source: completed by author.

One interesting phenomenon is that when the log of the odds becomes 0 or positive, SMEs do not provide collateral to qualify for loans.

Table 4. Regression Result

Dependent Variable: L; Method: Least Squares

Date: 12/11/18 Time: 08:13

Sample(adjusted): 17

Included observations: 6; Excluded observations: 1 after adjusting endpoints

\begin{tabular}{|l|c|c|c|c|}
\hline \multicolumn{1}{|c|}{ Variable } & Coefficient & Std. Error & t-Statistics & Prob. \\
\hline X1 & 0.074167 & 0.085056 & 0.074167 & 0.085056 \\
\hline R-squared & 0.947550 & Mean dependent var & -0.361568 & \\
\hline Adjusted R-squared & 0.685025 & S.D. dependent var & 0.612153 & \\
\hline S.E. of regression & 0.340187 & Akaike info criterion & 0.942342 & \\
\hline Sum squared resid & 0.462754 & Schwarz criterion & 0.873123 & \\
\hline Log likelihood & -0.827323 & F-statistic & 10.92407 & \\
\hline Durbin-Watson stat & 0.537459 & Prob(F-statistic) & 0.076428 & \\
\hline
\end{tabular}

Source: completed by author. 
There is a positive correlation between the log of the odds (L) and the levels of accounting practices. This connotes that any improvement in accounting practice results in a corresponding reduction in financial challenges due to the increase in access to finance. This is because lenders, banking or non-banking institutions will be willing to extend credit to SMEs with reliable accounting practices. Similarly, an improved accounting practice has a significant impact in management proficiency. In other words, SMEs will be more capable of managing their businesses under a sound accounting practices since all the data needed for decision making are made available. This result is in harmony with the preliminary results shown above. The log of the odds does not have a positive correlation with collateral facility(x2). We can assert that loans to SMEs in Nigeria do not necessarily depend on the ability of the SMEs to provide collateral security. However, for R-squared of 0.947550, Adjusted R-squared of 0.6850 and a significant $F$ value, the two variable X1 and X2 can combined together to improve the financial conditions of the SMEs to a great extent.

\subsection{Conclusion}

This paper evaluates the significance of accounting information in reducing the financial challenges of SMEs in Nigeria. From all the available empirical evidences, it is empirically necessary to conclude that SMEs in Nigeria have a poor and porous accounting system in Nigeria. The study also concludes that sound accounting practices have a positive correlation with access to funding by small and medium enterprises in Nigeria. The higher the quality of accounting information generated by the SMEs (as shown by the designated level of accounting practice), the more access the SMEs will have to finance. The null hypothesis which says SMEs in Nigeria have no sound accounting practices is accepted while we reject the second null hypothesis which says that access to funding by SMEs is not dependent on the quality of accounting practices. Similarly, we reject the null hypothesis which says access to funding by MSMEs does not depend on availability of collateral. This means the higher the quality of collateral offered by MSMEs, the higher their chances of getting finances.

\subsection{Recommendations}

Based on the findings and the literature reviewed, the study hereby makes the following empirical recommendations:

1. SMEs should install a sound internal control system in order to reduce the porosity of their accounting and asset management systems.

2. SMEs should ensure a sound accounting practice that conforms with the internationally accepted accounting standards in order to boost their access to funding. This can be achieved by engaging the services of professional accountants.

3. MSMEs should invest a portion of their capital in non-current assets in order to increase the value of their collaterals and, hence, have expansive access to funding.

\section{References}

1. Jibir, (2015). Microfinance institutions and the development of SMEs in Gombe State of Nigeria. International Journal of Banking, Finance, Management and Development Studies, 1(5), 72-88.

2. Aldrich, J. H. and F. Nelson (1984). Linear Probability, Logit and Probit Models, Chicago: Sage publications.

3. Amemiya, T. (1981). Qualitative Response Regression Models, Journal of Economic Literature, 19, 331-354.

4. Aremu, M.A., Adeyemi, S. L. (2011). Small and Medium Scale Enterprises as survival strategy for Employment Generation in Nigeria, Journal of sustainable Development, 4(1). Retrieved November 2 from www.ccsenet.org/jsd

5. Aremu, M. A. (2010). Small and Medium Scale Enterprises Capacity Building in Nigeria, A paper presented at the International Conference on management and Enterprise Development on Intellectual 
and New Strategies for Sustainability Development of the Third World, Held at Conference Centre, University of Ibadan, Nigeria Oct.5th $-8^{\text {th }}$.

6. D. Motilewa, M. Ogbari, \& D. O. Aka, (2015). A review of the impacts SMEs as social agents of economic liberations in developing economies. International Review of Management and Business Research, 4(3), 903-914.

7. Beck, T., A. Demirguc-Kunt, L. Laeven, R. Levine. (2008). Finance, firm size and growth. Journal of Money, Credit, and Banking, 40(7), 1379-1405.

8. Beck. T. Demirguc-Kunt. A. \&Maksimovic. V. (2005). Financial and legal constraints to firm growth: does firm size matter? Journal of Finance. 60, 137-177.

9. Bekele, E. Zeleke, W. (2008). Factors that affect the long-term survival of micro, small and medium enterprises in Ethiopia. South African Journal of Economics, 76(3),1-33.

10. Berger A.N. and Black L.K. (2011). Bank size, lending technologies, and small business finance, Journal of Banking \& Finance, 35, 724-735

11. Berger A.N. and Udell G.F. (1998). The Economics of Small Business Finance: The Roles of Private Equity and Debt Markets in the Financial Growth Cycle, Journal of Banking and Finance, 22.

12. Berger A.N. and Udell G.F. (2002). Small business credit availability and relationship lending: The importance of bank organizational structure, Economic Journal, 112, F32-F35.

13. Berger A.N. and Udell G.F. (2006). A more complete conceptual framework for SME finance, Journal of Banking \& Finance 30, 2945-2966.

14. Central Bank of Nigeria. (2016). Statistical Bulletin. Abuja, Nigeria.

15. E. T. Chinweuba, \& C. O. Sunday. (2015). Quantitative analysis of the impact of small and medium scale enterprises on the growth of Nigerian economy: (1993-2011). International Journal of Development and Emerging Economics, 3(1), 26-38.

16. Gujarati, D. N., Porter D.C. (2009). Basic Econometrics, New York: McGrawHill, fifth Edition.

17. I. B. Kadiri. (2012). Small and medium scale enterprises and employment generation in Nigeria: the role of finance. Kuwait Chapter of Arabian Journal of Business and Management Review, 1(9), 79-94.

18. K. Odubajo. (2001). Relevance of small-scale enterprises in development of Nigerian. Economy Journal of Banking, 8(6), 14-19.

19. L. Anthony \& S. Arthur, (2008). The role of micro, small and medium enterprises in economic growth: across-country regression analysis, United States Agency for International Development Micro-Report, 135 .

20. Larry, M. B. (1997). Econometrics and Presidential Elections, Journal of Economic Perspectives, 11(3), 195-196.

21. M. A. Carree., Vanstel. A. J. Thurik. A. R. \& A. R. M. Wennekers. (2002). Economic development and business ownership: an analysis using data of 23 OECD countries in the period 1976-1996, Small Business Economic, 19, 217-290.

22. M. A. Taiwo, A. M. Ayodeji, \& B. A. Yusuf, (2012). Impact of SMEs on Economic Growth and Development. American Journal of Business and Management, 1(1), 18-22.

23. M. O. Afolabi. (2013). Growth effect on small and medium enterprises (SMEs) financing in Nigeria, Journal of African Macroeconomic Review, 3(1), 193-205.

24. Ministry of Commerce and Industry (2009) Field surveyMoghadden, G. and E. Hallie (2009). Predicting the Incumbent party vote shares in U.S Presidential Elections, Cato Journal, 29,455-468.

25. Nagaya N., (2017). SME impact on output growth, case study of India. Palma Journal, 16(13), 11-170.

26. Obamuyi, T. M. (2007). An Exploratory Study of Loan Delinquency among Small and Medium Enterprise (SMEs) in Ondo State of Nigeria, Labour and Management Development Journal, 8, $1-10$

27. OECD (2006). The SME Financing Gap. Theory and Evidence, Volume I, OECD, OECD Publishing.

28. OECD (2009). Financing high growth and innovative start-ups and SMEs: data and measurement issues, OECD. Paris, COM/STD/CFE/SME(2008)2/FINAL.

29. OECD (2010a), High Growth Enterprises. What Governments can do to make a difference? OECD Publishing. OECD (2010b). Assessment of government support programmes for SMEs' and entrepreneurs' access to finance in the global crisis, OECD, Paris. 
30. OECD (2010c). SMEs, Entrepreneurship and Innovation, OECD Publishing

31. OECD (2010d). The OECD Innovation Strategy. Getting a head start on tomorrow, OECD Publishing

32. OECD (2011a). Financing High Growth Firms: The Role of Angel Investors, OECD Publishing. OECD (2011b), Entrepreneurship at a Glance 2011, OECD Publishing.

33. OECD (2011c). Business Innovation Policies. Selected country comparisons, OECD Publishing OECD (2012a), Financing SMEs and Entrepreneurs 2012: An OECD Scoreboard, OECD Publishing.

34. OECD (2012b). Entrepreneurship at a Glance 2012, OECD Publishing.

35. OECD (2013a). SME financing: Roadmap for future work - Addendum. Selected issues and overview of past and current work on SME finance at the OECD, OECD, Paris, DAF/CMF (2013)3/ADD1

36. OECD (2013b). Alternative Financing Instruments for SMEs and entrepreneurs: The case of Mezzanine Finance, OECD. Paris, CFE/SME (2012)9/FINAL.

37. OECD (2013c). Credit Mediation for SMEs and Entrepreneurs, OECD, Paris, CFE/SME (2011)8/FINAL.

38. OECD (2013d). The Role of Credit Guarantee Schemes and Mutual Guarantee Societies in supporting finance for small and medium-sized enterprises, OECD, Paris, CFE/SME (2012)1/FINAL.

39. OECD (2013e). Policies for seed and early stage finance: Summary of the 2012 OECD Financing Questionnaire, OECD, Paris, DSTI/IND (2013)5.

40. OECD (2013f). The role of banks, equity markets and institutional investors in long-term financing for growth and development. Report for G20 Leaders, Report presented at the Meeting of the G20 Finance Ministers and Central Banks Governors in Moscow, 15-16 February 2013.

41. OECD (2014a). SME debt financing beyond bank lending: the role of securitisation, bonds and private placements, OECD, Paris.

42. OECD (2014b), Italy: Key Issues and Policies, OECD Studies on SMEs and Entrepreneurship, OECD Publishing.

43. OECD (2014c), New approaches to SME and entrepreneurship finance: the case of crowdfunding, OECD, Paris, CFE/SME (2013)/7/REV2/ANN1.

44. OECD (2014d), Entrepreneurship at a Glance 2014, OECD Publishing.

45. OECD (2014e), New Approaches to Economic Challenges. Synthesis Report, Meeting of the OECD Council at Ministerial Level, Paris, 6-7 May.

46. OECD (2014f), Public SME Equity Financing - Exchanges, Platforms, Players, OECD Financial Roundtable meeting, 23 October 2014, OECD, Paris, DAF/CMF (2014)1.

47. Ogujiuba, K. K., F. K. Ohuche and A. O. Adenuga (2004). Credit Availability to small and medium scale enterprises in Nigeria: Importance of new capital base for banks- background and issues", AIAE working paper.

48. Olorunshola, J. A. (2003). Problems and Prospects of Small and Medium Scale Industries in Nigeria, Seminar on Small and Medium Scale Industries Equity Investments Equity Scheme, Publication No. 4, CBN Training Centre, Lagos.

49. Olorunshola, J. A. (2003). Problems and Prospects of Small and Medium Scale Industries in Nigeria, Seminar on Small and Medium Scale Industries Equity Investments Equity Scheme, Publication, 4, CBN Training Centre, Lagos.

50. R. Nalini, R. Alamelu, R. Amudha, L.C.S. Motha. (2016). Financial literacy and its contributing factors in investment decisions among urban populace. Indian Journal of Science and Technology. 9(27), 1-9.

51. R. Thurik, \& S. Wennekers. (2004). Entrepreneurship, small businesses and economic growth. Journal Small Business and Entrepreneurship Development, 1(1), 140-149

52. R. Thurik, \& S. Wennekers. (2004). Entrepreneurship, small businesses and economic growth. Journal Small Business and Entrepreneurship Development, 1(1), 140-149.

53. S. Vijayakumar. (2013). The trend and impact of SMEs on economic growth of Sri Lanka. Journal of Global Business Management and Research, 2(1), 39-47.

54. T. A. Cravo, A. Gourlay, \& B. Becker. (2009). SME and regional economic growth in Brazil. WP 201001. 
Financial Markets, Institutions and Risks, Volume 3, Issue 3, 2019

ISSN (online) - 2521-1242 ISSN (print) - 2521-1250

55. Taiwo, A., A. M. Ayodeji and A. B. Yusuf. (2012). Impact of Small and Medium Enterprises on Economic Growth and Development, American Journal of Business and Management 1(1), 18-22

56. Udechukwu, F.N. (2003). Survey of Small and Medium Scale Industries and their Potentials in Nigeria, Seminar on Small and Medium Industries Equity Investments Scheme, publication No. 4, CBN training centre, Lagos.

57. Y. M Kaigama, N.A Talib, H. Ashari. (2016). Moderating effect of financial literacy in the relationship between microfinance banks and small business survival. Indian Journal of Innovations and Developments. 5(12), December. 